\title{
Fertility Life Table of Leucoptera coffeella (Guérin-Mèneville) (Lepidoptera: Lyonetiidae) at Seven Temperatures in Coffee
}

\author{
Marisol Giraldo-Jaramillo ${ }^{1,}$, , Javier Garcia-Gonzalez ${ }^{2}$, Johanna Bajonero Rugno ${ }^{3}$ \\ ${ }^{1}$ Entomology Department, National Center for Coffee Crop Research, CENICAFE Manizales, Colombia \\ ${ }^{2}$ Agriculture Department, Laserlit Precision, Bogotá, Colombia \\ ${ }^{3}$ Entomology and Acarology Department, University of São Paulo/ESALQ Piracicaba, Brazil
}

Email address:

Marisol.giraldo@cafedecolombia.com (M. Giraldo-Jaramillo), javiggonzalez@gmail.com (J. Garcia-Gonzalez), johabajonero@gmail.com (J. B. Rugno)

${ }^{*}$ Corresponding author

\section{To cite this article:}

Marisol Giraldo-Jaramillo, Javier Garcia-Gonzalez, Johanna Bajonero Rugno. Fertility Life Table of Leucoptera coffeella (GuérinMèneville) (Lepidoptera: Lyonetiidae) at Seven Temperatures in Coffee. American Journal of Entomology. Vol. 3, No. 4, 2019 , pp. 70-76. doi: $10.11648 /$ j.aje.20190304.12

Received: September 12, 2019; Accepted: October 4, 2019; Published: December 10, 2019

\begin{abstract}
Coffee leaf miner Leucoptera coffeella (Guérin-Mèneville, 1842) (Lepidoptera: Lyonetiidae) it is a one biggest insect pest of coffee in American continent coffee plantations, due to its generalized occurrence, since all coffee varieties are susceptible to attack, and the economic damage caused, which can involve production losses up to $50 \%$. The present study investigated biological aspects, including the fertility life table and the ideal conditions for reproduction and development of this pest, at 7 constant temperatures $\left(18,22,25,28,30,32,35^{\circ} \mathrm{C}\right)$ under laboratory conditions. The results showed that the mean biological development time of $L$. coffeella was affected by temperature, completing its life cycle more rapidly in increased temperatures until the $32^{\circ} \mathrm{C}$, but low survivor of all L. coffeella stages was observed from $30^{\circ} \mathrm{C}$. The preoviposition period decreased with increasing temperatures, the total fecundity was significantly affected by the temperature and the longevities of males and females were affected by the temperature. The highest net reproductive rate (22.23), finite rate of increase $(0.15)$ and viability were observed at $28^{\circ} \mathrm{C}$, indicating that this temperature was the most suitable for development. The information obtained can be used in integrated pest management programs, to forecast $L$. coffeella outbreaks and population growth, and to study the behavior of this insect under different climate conditions
\end{abstract}

Keywords: Coffee Leaf Miner, Biology, Coffee Var. Obatã

\section{Introduction}

In Brazil, Leucoptera coffeella (Lepidoptera: Lyonetiidae) is a major insect pest of coffee $[1,2]$. It occurs over a wide area of the country and attacks all coffee varieties [3]. The pest causes significant economic damage [4], with production losses up to $50 \%$ [5].

The biology of this insect pest has been studied in several different coffee varieties [4, 6]. Egg-adult development varies with the coffee variety, temperature conditions, relative humidity, and rainfall [1, 4]. Temperature is the most important abiotic factor, affecting fecundity, reproduction, development time, emergence rate, and longevity [7, 8]. Climate changes may potentially affect many aspects of insect life cycles and ecology, especially those controlled by variables related to the availability of energy, e.g., degreedays. Birth and mortality rates of an insect population are determined by different biotic and abiotic factors [9].

The fertility life table is an appropriate method to study arthropod population dynamics because it allows estimation of parameters related to the growth potential of these populations [10]. Parra et al. [11] studied the fertility life table of $L$. coffeella at three constant temperatures $(20,27$ and $30^{\circ} \mathrm{C}$ ) in the Mundo Novo coffee variety and defined $27^{\circ} \mathrm{C}$ as the optimal temperature for maximum population 
growth rate.

The present study evaluated the effect of seven constant temperatures on the development of L. coffeella on leaves of the Obatã coffee variety, determining the fertility life table and optimal conditions for reproduction and development of this pest. This study provided new information on biological parameters of the coffee leaf miner on this coffee variety, over a wide range of temperatures.

\section{Materials and Methods}

Coffee leaves of the Obatã variety with larvae and pupae of coffee leaf miners were collected in the experimental area at the Department of Entomology and Acarology, ESALQUSP, Piracicaba $\left(22^{\circ} 42^{\prime} 51.0366^{\prime \prime S}, 47^{\circ} 37^{\prime} 41.556^{\prime \prime} \mathrm{W}, 548\right.$ $\mathrm{m})$, São Paulo state, Brazil.

For insect rearing, a method developed by Parra [4] was used. Infested leaves were taken to the laboratory and maintained in conical cages until adult emergence. Emerging adults were separated by sex based on external characteristics of the last abdominal segment. The adults were placed in rearing cages $(40 \times 40 \times 50 \mathrm{~cm})$ covered with a voile cloth. Coffee leaves on the third and fourth internodes (higher photosynthetic activity) were used as the oviposition substrate. The leaves were maintained in floral foam moistened with deionized water and covered with voile. Leaves were added, eggs counted, and dead insects removed daily. Pairs were maintained in a climate-controlled chamber at $25 \pm 2{ }^{\circ} \mathrm{C}, 65 \pm 10 \% \mathrm{RH}$ and a photoperiod of $14: 10 \mathrm{~h}$ [L:D].

\subsection{Biology of L. coffeella in Different Temperatures}

The biology of L. coffeella was studied in climatecontrolled chambers regulated at temperatures of 18, 22, 25, $28,30,32$ and $35 \pm 1^{\circ} \mathrm{C}, 65 \pm 10 \% \mathrm{RH}$ and photoperiod $14: 10$ $\mathrm{h}$ [L:D].

The study was initiated with a colony composed of 2100 eggs, divided into 7 treatments with 6 replicates each. Each replicate per treatment consisted of 50 eggs. Leaves with eggs were maintained in conical cages on the bottom with moistened filter paper. After the larvae hatch, they damage the upper epidermis of the leaf and burrow into the mesophyll, feeding on parenchyma cells. The larvae were maintained in conical cages during all larval and pupal stages until adult emergence. Developmental metrics included the duration and viability of the egg-adult period, duration of the preoviposition and oviposition periods, fecundity, and adult longevity. After adult emergence, 30 pairs of moths from each temperature were placed in a single-pair mating system at the same temperature. As described by Parra [4], the pairs were maintained in a conical cage $(13.5 \times 3 \times 4.5 \mathrm{~cm})$ (height $\times$ radius of upper base $\times$ radius of lower base) with coffee leaves of the Obatã variety, closed with voile. To feed the adults, a braided cotton roll soaked in $10 \%$ sucrose solution was placed on the voile [4]. Coffee leaves were changed and the number of eggs was counted daily, using a stereomicroscope $(10 \times)$. The mortality of males and females was also determined. The experiment was concluded when all adults died.

Data from all tests were submitted to a Shapiro-Wilk test $(\mathrm{P}<0.05)$ to verify the normality, as well as a Bartlett's test $(\mathrm{P}<0.05)$ to verify the homoscedasticity. The data for the eggadult period, viability and number of eggs per female were submitted to the analysis of variance by the GLM procedure and the means were compared by Tukey test at $5 \%$ significance [12]. The values for sex ratio, $\mathrm{sr}=$ (number of females)/(number of females + number of males), were analyzed by the chi-square test $(\mathrm{P}<0.05)$ in $\mathrm{R}[12]$.

\subsection{Fertility Life Table of L. coffeella at Different Temperatures}

In order to obtain the fertility life tables at each temperature, the number of eggs per female $\left(m_{x}\right)$ on each day $(x)$ and the proportion of the number of females surviving to the next day were calculated. Then, the fertility life table was constructed according to Maia et al. [10]. The following parameters were estimated: generation time $(T)$ (eq. 1), net reproductive rate $\left(R_{0}\right)$ (eq. 2$)$, intrinsic rate of increase $\left(r_{m}\right)$ (eq. 3 ) and finite rate of increase ( $($ ) (eq. 4 ).

$$
\begin{gathered}
R o=\Sigma l_{x} \cdot m_{x} \\
r_{m}=\frac{\ln (R o)}{T} \\
T=\frac{\ln (\mathrm{Ro})}{\mathrm{r}_{m}} \\
\Lambda=\mathrm{e}^{\mathrm{r}_{m}}
\end{gathered}
$$

The bootstrap technique was used to calculate the variance of the estimated parameters, according to Meyer et al. [13], using $\mathrm{R}$ version 3.2.3 [12].

\section{Results and Discussion}

\subsection{Biology of Leucoptera coffeella at Different Temperatures}

Temperature significantly influenced the incubation period of eggs, which varied from 3.1 days at $35^{\circ} \mathrm{C}$ to 10.3 days at $18^{\circ} \mathrm{C} \quad\left(F_{6,33}=168.11, P<0.001\right)$ and stabilized at temperatures higher than $25^{\circ} \mathrm{C}$ (Figure 1). Although the incubation periods were progressively shorter at higher temperatures, egg viability was significantly reduced only at $35^{\circ} \mathrm{C}$ (Table 1), as also observed by Parra [4]. Authors such as Notley [14] and Magalhães et al. [15] have noted that differences in the viability of this stage may be associated with other environmental factors besides the temperature, e.g., with genotypes of Coffea arabica.

The mean duration of larval development was 7.1 days at $32^{\circ} \mathrm{C}$ to 21.6 days at $18^{\circ} \mathrm{C}\left(F_{5,30}=178.3, P<0.001\right)$ and stabilized at temperatures higher than $25^{\circ} \mathrm{C}$, as also found by Parra [4] (Figure 1). Larvae failed to complete their development at $35^{\circ} \mathrm{C}$. The mean durations of larval development were longer than those reported by Parra [4], probably because that study used a different coffee variety (Mundo Novo). According to Magalhães et al. [15], the development time of the coffee leaf miner varies because of 
the chemical compounds in different varieties of Brazilian coffee. At temperatures above $28^{\circ} \mathrm{C}$, larval viability decreased (Table 1), as also observed by Parra [4]; Katiyar and Ferrer [16].

Temperature significantly influenced the pupal development $\left(F_{5,30}=109.91, P<0.001\right)$, which varied from 3.5 days at $32^{\circ} \mathrm{C}$ to 14.7 days at $18^{\circ} \mathrm{C}$ (Table 1). Pupal development was not observed at $35^{\circ} \mathrm{C}$. As in the other stages, the higher the temperature, the shorter the development time, with a more stable behavior at higher temperatures (Figure 1). Pupal development times were similar to those reported by Parra [4] and Katiyar and Ferrer [16]. Pupal viability was highest at $25^{\circ} \mathrm{C}$, decreasing above and below this temperature.

At temperatures of $30^{\circ} \mathrm{C}$ and above, pupal malformations

Egg
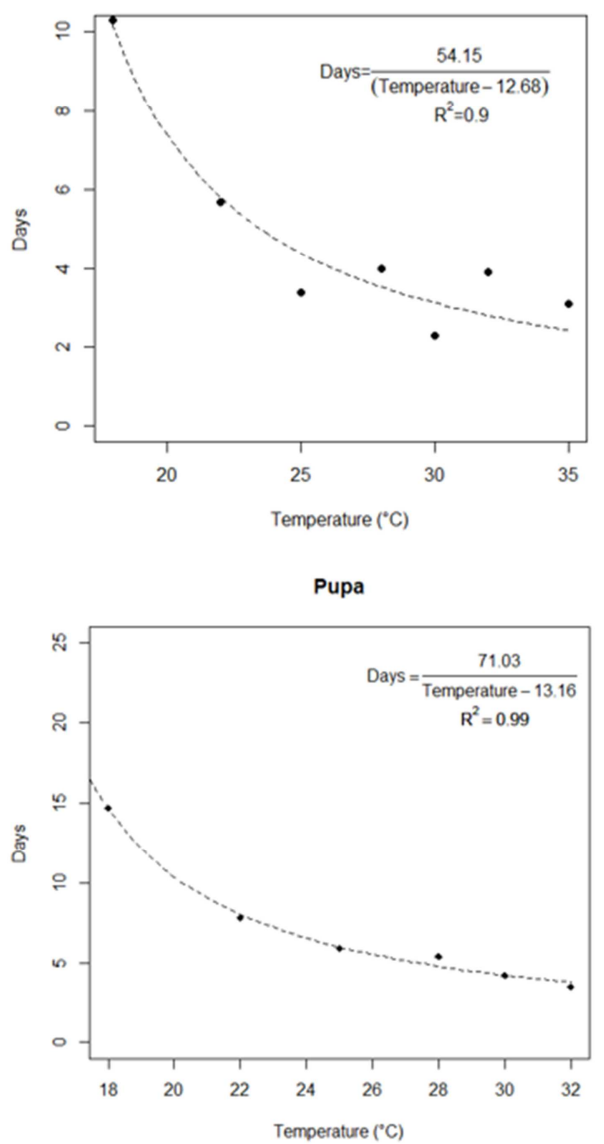

were observed; only $80 \%$ of the individuals at $30^{\circ} \mathrm{C}$ and $66 \%$ at $32^{\circ} \mathrm{C}$ showed the " $\mathrm{X}$ " shape of normal pupae. Individuals that failed to produce a cocoon $\left(20 \%\right.$ at $30^{\circ} \mathrm{C}$ and $34 \%$ at $32^{\circ} \mathrm{C}$ ) dried out in the high temperatures, since the cocoons provide a proteinaceous shelter produced from the labial glands, to protect the insects from environmental stress [17].

The development time of the egg-adult period was significantly affected by the temperature between $18^{\circ} \mathrm{C}$ and $32^{\circ} \mathrm{C}\left(\mathrm{F}_{5,30}=7224 ; \mathrm{P}<0.001\right)$ (Table 1$)$, ranging from 11.53 days at $32^{\circ} \mathrm{C}$ to 46.62 days at $18^{\circ} \mathrm{C}$. Viability did not differ significantly from $18^{\circ} \mathrm{C}$ to $28^{\circ} \mathrm{C}$, ranging from $50 \%$ at $32^{\circ} \mathrm{C}$ to $70 \%$ at $18^{\circ} \mathrm{C}$, with a peak at $25^{\circ} \mathrm{C}(89 \%)$, similar to the variation found by Notley [14] in coffee leaf miners on Mount Kilimanjaro in Africa.
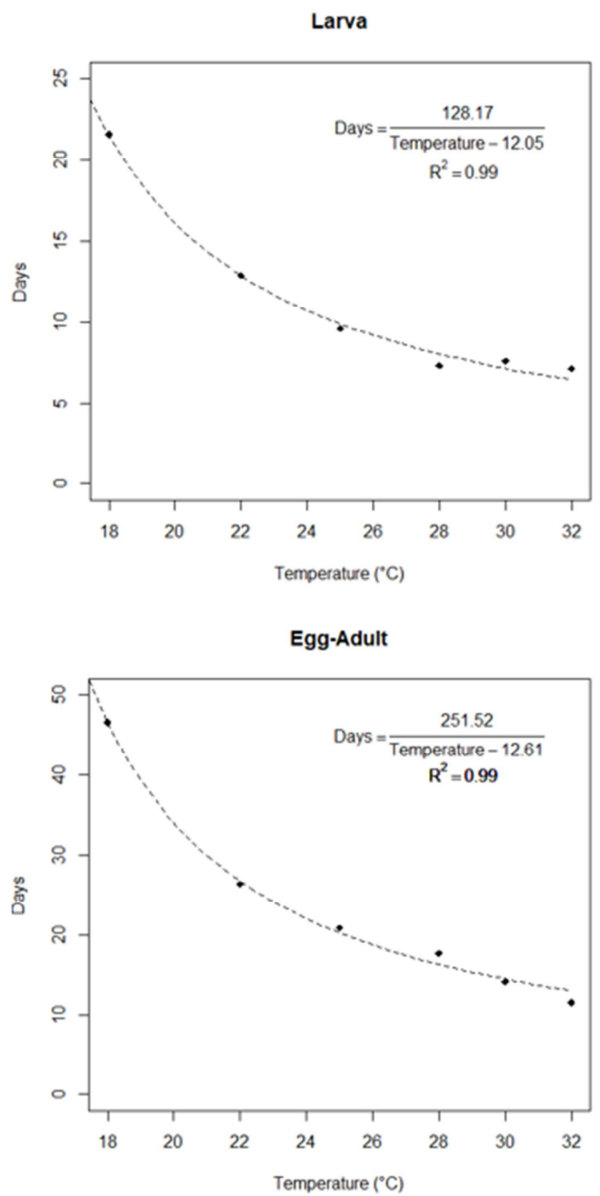

Figure 1. Development of Leucoptera coffeella at seven constant temperatures on coffee leaves of the Obatã variety. RH 65 $10 \%$ and photoperiod of $14: 10 \mathrm{~h}$ $(L: D)$.

In the present study, although the viability of the egg-adult period decreased as the temperature moved away from $25^{\circ} \mathrm{C}$, enough individuals survived at all temperatures (except $35^{\circ} \mathrm{C}$ ) to allow construction of a fertility life table. The temperature did not significantly influence the sex ratio (Table 1) $\left(\mathrm{X}^{2}=0.98, \mathrm{p}=0.5718\right)$, which varied from 0.55 to 0.57 , as found by Parra [4]. The preoviposition period decreased with increasing temperatures $\left(\mathrm{F}_{5,28}=115.3\right.$; $\mathrm{P}<0.001$ ) (Table 2). Females of $L$. coffeella initiated oviposition 12.4 days after adult emergence at $18^{\circ} \mathrm{C}$, but only 1.4 days after emergence at $32^{\circ} \mathrm{C}$. Total fecundity (mean number of eggs laid per female) was significantly affected by the temperature $\left(\mathrm{F}_{5,28}=74.5 ; \mathrm{P}<0.001\right)$, and was highest at 25 and $28^{\circ} \mathrm{C}$, with 64.9 and 60.3 eggs per female, respectively. The negative relationship between oviposition and temperature (Table 2) was similar to the findings of Notley [14] for populations in Africa. On the Obatã coffee variety, coffee leaf miners laid the most eggs at 25 and $28^{\circ} \mathrm{C}$. 
Table 1. Mean duration and viability of the egg, larval, pupal and egg-adult periods, and sex ratio ( \pm SE $\left.{ }^{a}\right)$ of Leucoptera coffeella, at seven constant temperatures on coffee leaves of the Obatã variety. RH 65 $10 \%$ and photoperiod of 14:10 (L:D).

\begin{tabular}{|c|c|c|c|c|c|c|c|c|}
\hline \multirow{2}{*}{ Temperature $\left({ }^{\circ} \mathbf{C}\right)$} & \multicolumn{8}{|c|}{ Duration (days) * } \\
\hline & $\mathbf{n}$ & Egg & $\mathbf{N}$ & Larva & $\mathbf{n}$ & Pupa & $\mathbf{n}$ & Egg-adult \\
\hline 18 & 300 & $10.3 \pm 0.2 \mathrm{a}$ & 272 & $21.6 \pm 0.8 \mathrm{a}$ & 246 & $14.7 \pm 0.3 \mathrm{a}$ & 209 & $46.6 \pm 1.3 \mathrm{a}$ \\
\hline 22 & 300 & $5.7 \pm 0.0 \mathrm{~b}$ & 280 & $12.9 \pm 0.2 b$ & 261 & $7.8 \pm 0.1 \mathrm{~b}$ & 236 & $26.4 \pm 0.3 b$ \\
\hline 25 & 300 & $3.4 \pm 0.2 \mathrm{c}$ & 291 & $9.6 \pm 0.3 \mathrm{bc}$ & 263 & $5.9 \pm 0.2 \mathrm{c}$ & 248 & $20.9 \pm 0.7 \mathrm{c}$ \\
\hline 28 & 300 & $4.0 \pm 0.1 \mathrm{c}$ & 282 & $7.3 \pm 0.2 \mathrm{c}$ & 262 & $5.4 \pm 0.4 \mathrm{c}$ & 229 & $17.7 \pm 0.7 \mathrm{c}$ \\
\hline 30 & 300 & $2.3 \pm 0.1 \mathrm{c}$ & 265 & $7.6 \pm 0.4 \mathrm{c}$ & 214 & $4.2 \pm 0.3 \mathrm{~cd}$ & 208 & $14.2 \pm 0.2 \mathrm{~cd}$ \\
\hline 32 & 300 & $3.9 \pm 0.3 \mathrm{c}$ & 257 & $7.1 \pm 0.6 \mathrm{c}$ & 208 & $3.5 \pm 0.3 \mathrm{~d}$ & 167 & $11.5 \pm 0.1 \mathrm{~d}$ \\
\hline 35 & 300 & $3.1 \pm 0.4 \mathrm{c}$ & 105 & - & - & - & - & \\
\hline
\end{tabular}

Table 1. Continued.

\begin{tabular}{|c|c|c|c|c|c|}
\hline \multirow{2}{*}{ Temperature $\left({ }^{\circ} \mathrm{C}\right)$} & \multicolumn{4}{|c|}{ Viability (\%) } & \multirow{2}{*}{ Sex ratio** } \\
\hline & Egg & Larva & Pupa & Egg-adult & \\
\hline 18 & $91 \pm 1.6 \mathrm{a}$ & $88 \pm 3.6 a$ & $85 \pm 3.0 \mathrm{a}$ & $70 \pm 5.9 a$ & $0.56 \mathrm{a}$ \\
\hline 22 & $93 \pm 3.9 \mathrm{ab}$ & $90 \pm 5.6 \mathrm{ab}$ & $90 \pm 4.6 \mathrm{ab}$ & $75 \pm 4.7 \mathrm{ab}$ & $0.57 \mathrm{a}$ \\
\hline 25 & $97 \pm 2.7 b$ & $97 \pm 2.6 b$ & $95 \pm 3.4 \mathrm{ab}$ & $89 \pm 7.1 b$ & $0.56 \mathrm{a}$ \\
\hline 28 & $94 \pm 1.8 b$ & $93 \pm 3.8 b$ & $87 \pm 4.4 a$ & $76 \pm 6.9 \mathrm{ab}$ & $0.57 \mathrm{a}$ \\
\hline 30 & $88 \pm 2.3 \mathrm{a}$ & $81 \pm 5.8 c$ & $78 \pm 6.7 \mathrm{c}$ & $56 \pm 6.0 \mathrm{c}$ & $0.57 \mathrm{a}$ \\
\hline 32 & $86 \pm 3.4 a$ & $81 \pm 6.8 \mathrm{c}$ & $73 \pm 10.6 c$ & $50 \pm 8.9 c$ & $0.57 \mathrm{a}$ \\
\hline 35 & $35 \pm 8.9 \mathrm{c}$ & - & - & - & - \\
\hline
\end{tabular}

Means followed by the same letter in a column do not differ from one another (Tukey, $p<0.05^{*}$ and $X^{2}<0.05^{* *}$ ). $\mathrm{N}=$ number of individuals used in each treatment. ${ }^{\text {a }}$ Standard error.

The number of eggs per day varied according to the temperature. At the lowest temperature $\left(18^{\circ} \mathrm{C}\right)$, the highest number of eggs were laid between days 13 and 17 , whereas the oviposition peak was observed at 22 and $25^{\circ} \mathrm{C}$ on day 5
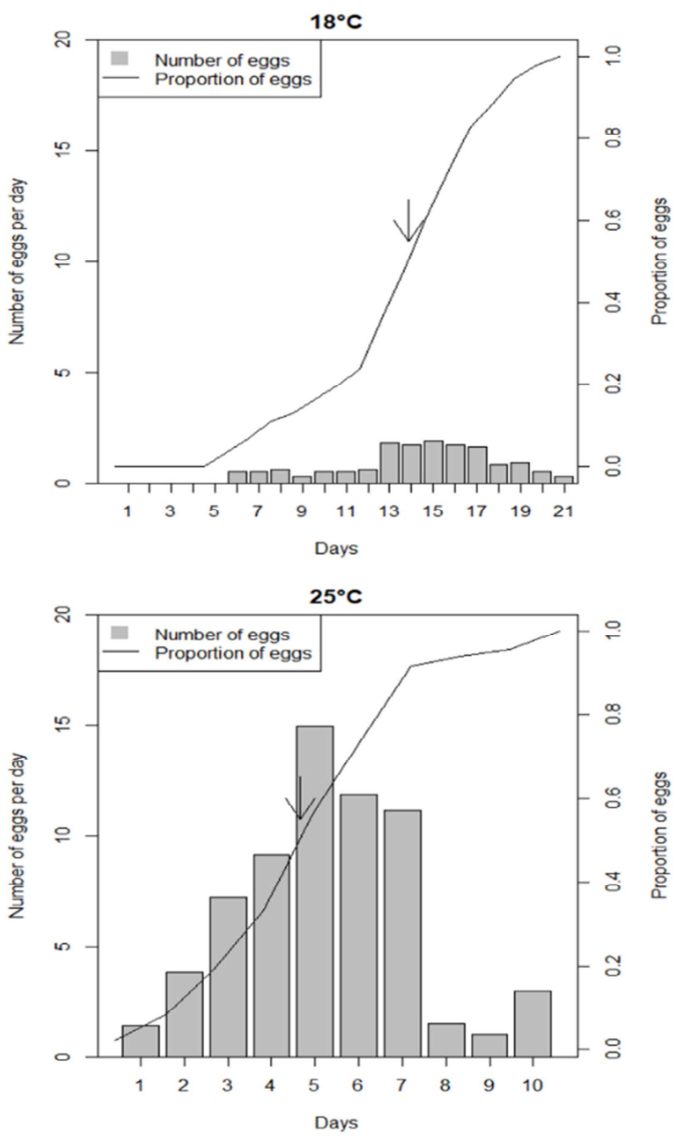

and at 28,30 and $32^{\circ} \mathrm{C}$ on day 3 (Figure. 2). Fifty percent of the total eggs were laid in the first six days (Figure 2), except at $18^{\circ} \mathrm{C}$, when $50 \%$ were laid by day 14 .
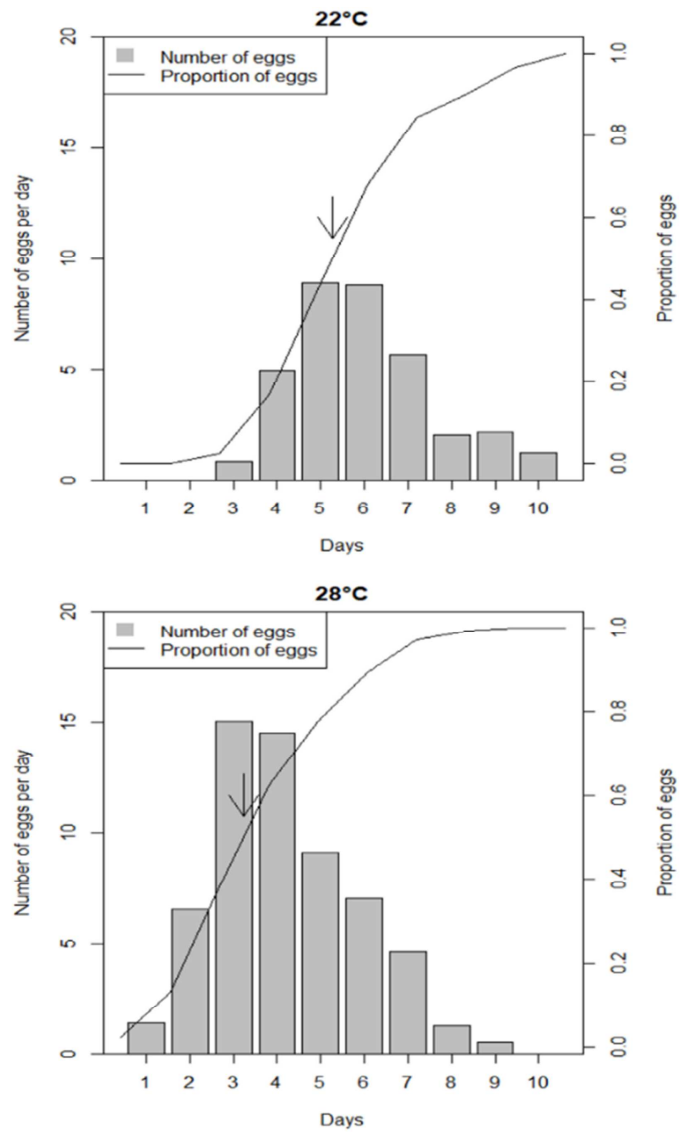

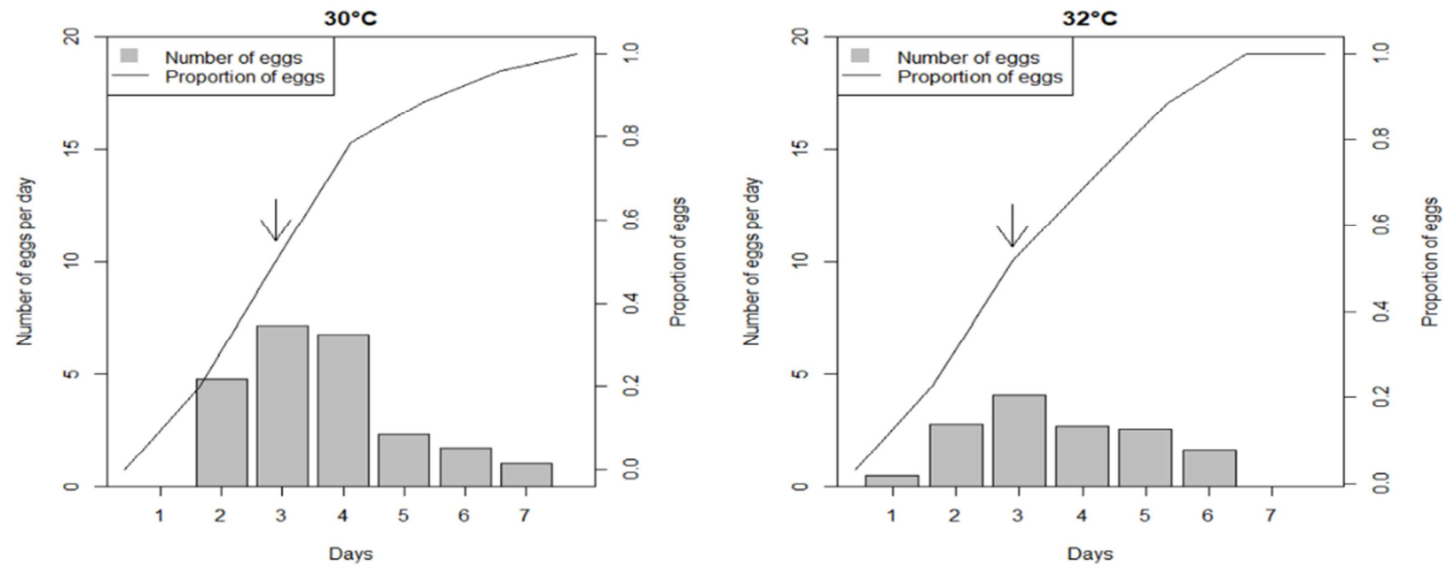

Figure 2. Mean number of eggs/female. day ${ }^{-1}( \pm S E)$ (histogram) and cumulative proportion of eggs laid by females of Leucoptera coffeella at six constant temperatures on coffee leaves of the Obatã variety. RH 65 $10 \%$ and photoperiod of 14:10 h [L:D]. Arrow indicates when the female laid 50\% of the total eggs.

Table 2. Preoviposition period and fecundity of Leucoptera coffeella at six constant temperatures on coffee leaves of the Obatã variety. RH $65 \pm 10 \%$ and photoperiod of $14: 10 \mathrm{~h}[\mathrm{~L}: \mathrm{D}]$.

\begin{tabular}{lllllll}
\hline \multirow{2}{*}{ Parameter } & \multicolumn{2}{l}{ Temperature $^{\circ} \mathbf{C}$} & & & \\
\cline { 2 - 7 } & $\mathbf{1 8}$ & $\mathbf{2 2}$ & $\mathbf{2 5}$ & $\mathbf{2 8}$ & $\mathbf{3 0}$ & $\mathbf{3 2}$ \\
\hline Pre-oviposition period (days) & $12.4 \pm 0.6 \mathrm{a}$ & $7.2 \pm 0.5 \mathrm{~b}$ & $3.4 \pm 0.2 \mathrm{c}$ & $2.9 \pm 0.3 \mathrm{~cd}$ & $1.6 \pm 0.2 \mathrm{~d}$ & $1.4 \pm 0.1 \mathrm{~d}$ \\
Mean number of eggs per female & $10.2 \pm 1.6 \mathrm{a}$ & $34 \pm 4.2 \mathrm{~b}$ & $64.9 \pm 3.6 \mathrm{c}$ & $60.3 \pm 3.8 \mathrm{c}$ & $23 \pm 2.1 \mathrm{~b}$ & $14.5 \pm 1.4 \mathrm{a}$ \\
\hline
\end{tabular}

Means followed by the same letter are not significantly different (Tukey, $p<0.05$ )

\subsection{Adult Longevity}

The longevities of males $\left(F_{5,98}=99.32 ; P<0.001\right)$ and females $\left(F_{5,98}=102.9 ; P<0.001\right)$ were significantly affected by the temperature. For males, longevity varied between 3.7 and 17.9 days, and for females, between 4.3 and 21.5 days, at $32^{\circ} \mathrm{C}$ and $18^{\circ} \mathrm{C}$ respectively (Table 3). This pattern resulted from the higher metabolism associated with an increase in temperature.

Table 3. Male and female longevities $( \pm S E)$ of Leucoptera coffeella at six constant temperatures on coffee leaves of the Obatã variety. RH $65 \pm 10 \%$ and photoperiod of 14:10 h [L:D].

\begin{tabular}{llll}
\hline \multirow{2}{*}{ Temperature $\left({ }^{\circ} \mathbf{C}\right)$} & \multirow{n}{*}{} & \multicolumn{2}{l}{ Period (days) Mean $\pm \mathbf{S E}$} \\
\cline { 3 - 4 } & & Males & Females \\
\hline 18 & 100 & $17.9 \pm 1.3 \mathrm{a}$ & $21.5 \pm 1.3 \mathrm{a}$ \\
22 & 100 & $11.5 \pm 0.5 \mathrm{~b}$ & $14 \pm 0.7 \mathrm{~b}$ \\
25 & 100 & $6.2 \pm 0.4 \mathrm{c}$ & $7.6 \pm 0.5 \mathrm{c}$ \\
28 & 100 & $6 \pm 0.2 \mathrm{c}$ & $8.6 \pm 0.4 \mathrm{c}$ \\
30 & 100 & $3.9 \pm 0.2 \mathrm{~cd}$ & $6.3 \pm 0.3 \mathrm{~cd}$ \\
32 & 100 & $3.7 \pm 0.2 \mathrm{~d}$ & $4.3 \pm 0.3 \mathrm{de}$ \\
\hline
\end{tabular}

Means followed by the same letter in a column are not significantly different (Tukey, $p<0.05$ ). $\mathrm{n}=$ number of individuals used in each treatment

\subsection{Fertility Life Table of Leucoptera Coffeella at Six Constant Temperatures}

The highest population growth rate was observed at $28^{\circ} \mathrm{C}$, when the net reproductive rate $\left(\mathrm{R}_{0}\right)$ was equal to $22.23(14.7-$ 32.3) (Table 4). At $35^{\circ} \mathrm{C}$, it was not possible to construct a fertility life table since adults were not obtained at this temperature. The $\mathrm{R}_{0}$ is defined as the average number of females that a female individual in a population will produce in its oviposition period, and is related to increases, decreases or stability in a population in each generation (18; 9). Parra et al. [11] found the highest value of $\mathrm{R}_{0}$ at $27^{\circ} \mathrm{C}$ (29.82), higher than the value obtained in the present study. The lowest values of $\mathrm{R}_{0}$ were obtained at the extreme temperatures $\left(18^{\circ} \mathrm{C}\right.$ and $\left.32^{\circ} \mathrm{C}\right)$, indicating that these temperatures are not suitable for the insect's reproduction.

The intrinsic rate of increase $\left(\mathrm{r}_{\mathrm{m}}\right)$ was positive in all temperatures, indicating that the population of coffee leaf miners increases in the temperature range $18-32^{\circ} \mathrm{C}$, varying from $0.03(0.00-0.05)$ at $18^{\circ} \mathrm{C}$ to $0.15(0.09-0.19)$ at $28^{\circ} \mathrm{C}$ (the highest $r_{m}$ observed) (Table 4). In Brazil, the largest infestations have been observed in dry periods, which usually extend from April to October. During rainy periods, populations are smaller [19].

The value of $r_{m}$ reflects the rate at which a population increases in size [9]. At the extreme temperatures (18 and $32^{\circ} \mathrm{C}$ ), the survival of immature stages and the fecundity both decreased. At $18^{\circ} \mathrm{C}$, the observed value can be associated with the long development times of the immature stages (Table 1) and pre-oviposition periods. At $32^{\circ} \mathrm{C}$, although the development time was shorter than at the other temperatures, the viability and fecundity were low, affecting the intrinsic rate of increase in the life table (Table 1).

The generation time $(\mathrm{T})$ corresponded with the biological data, since an inverse relationship between the development time and the temperature was also observed in the 18 to $30^{\circ} \mathrm{C}$ range (Table 4).

The values obtained for the finite rate of increase $(\lambda)$ ranged between $1.03(0.99-1.05)$ at $18^{\circ} \mathrm{C}$ and $1.16(1.09$ 1.21 ) at $28^{\circ} \mathrm{C}$ (Table 4). This parameter indicates the growth potential of an insect population and is therefore frequently used in insect control programs [20]. Based on the data for 
this parameter, populations of L. coffeella can potentially increase at all the temperatures $\left(18-32^{\circ} \mathrm{C}\right)$ studied here.

Table 4. Mean values of the parameters $(95 \%$ CI) of the fertility life table of Leucoptera coffeella, at six constant temperatures on coffee leaves of the Obatã variety. $\mathrm{RH} 65 \pm 10 \%$ and photoperiod of $14: 10 \mathrm{~h}$ [L:D].

\begin{tabular}{|c|c|c|c|c|c|c|}
\hline \multirow{2}{*}{ Parameter } & \multicolumn{6}{|c|}{ Temperature $^{\circ} \mathrm{C}$} \\
\hline & 18 & 22 & 25 & 28 & 30 & 32 \\
\hline $\mathrm{R}_{0}$ & $\begin{array}{l}5.12 \mathrm{a} \\
(0.75-9.76)\end{array}$ & $\begin{array}{l}14.26 \mathrm{~b} \\
(11.28-25.6)\end{array}$ & $\begin{array}{l}18.91 \mathrm{~b} \\
(15.29-22.78)\end{array}$ & $\begin{array}{l}22.23 \mathrm{~b} \\
(14.76-32.3)\end{array}$ & $\begin{array}{l}7.08 \mathrm{ab} \\
(0.9-15.23)\end{array}$ & $\begin{array}{l}4.09 \mathrm{a} \\
(0.77-7.78)\end{array}$ \\
\hline $\mathrm{r}_{\mathrm{m}}$ & $\begin{array}{l}0.03 \mathrm{a} \\
(0.00-0.05)\end{array}$ & $\begin{array}{l}0.08 \mathrm{~b} \\
(0.04-0.11)\end{array}$ & $\begin{array}{l}0.11 \mathrm{~b} \\
(0.06-0.14)\end{array}$ & $\begin{array}{l}0.15 \mathrm{~b} \\
(0.09-0.19)\end{array}$ & $\begin{array}{l}0.14 \mathrm{ab} \\
(0.00-0.19)\end{array}$ & $\begin{array}{l}0.10 \mathrm{ab} \\
(0.00-0.15)\end{array}$ \\
\hline $\mathrm{T}$ & $\begin{array}{l}48.80 \mathrm{a} \\
(47.45-50.51)\end{array}$ & $\begin{array}{l}31.15 b \\
(29.55-32.69)\end{array}$ & $\begin{array}{l}23 \mathrm{c} \\
(22.33-25.68)\end{array}$ & $\begin{array}{l}20.54 \mathrm{c} \\
(22.48-48.87)\end{array}$ & $\begin{array}{l}13.86 \mathrm{~d} \\
(12.5-15.67)\end{array}$ & $\begin{array}{l}13.79 \mathrm{~d} \\
(12.40-15.37)\end{array}$ \\
\hline$\Lambda$ & $\begin{array}{l}1.03 \mathrm{a} \\
(0.99-1.05)\end{array}$ & $\begin{array}{l}1.09 \mathrm{a} \\
(1.04-1.12)\end{array}$ & $\begin{array}{l}1.13 \mathrm{a} \\
(1.07-1.15)\end{array}$ & $\begin{array}{l}1.16 \mathrm{a} \\
(1.09-1.21)\end{array}$ & $\begin{array}{l}1.15 \mathrm{a} \\
(1.00-1.21)\end{array}$ & $\begin{array}{l}1.10 \mathrm{a} \\
(0.98-1.16)\end{array}$ \\
\hline
\end{tabular}

$\mathrm{R}_{0}=$ net reproductive rate, $\mathrm{r}_{\mathrm{m}}=$ intrinsic rate of increase, $\mathrm{T}=$ generation time, $\lambda=$ finite rate of increase. Means followed by the same letter in a line do not differ significantly $(95 \% \mathrm{CI})$. Parameters compared by bootstrap analysis $(10,000$ repetitions).

\section{Conclusion}

The results of this study confirmed the effect of temperature over the range of 18 to $32^{\circ} \mathrm{C}$ on the biology, reproductive and population parameters of $L$. coffeella. In coffee leaf miner increasing temperatures reduces preoviposition period and eclosion time of the laid eggs, key biological factors to consider when new pest populations are arriving to new crop systems.

In the same line, L. coffeella showed an optimal developmental and biological fitness at temperature of $28^{\circ} \mathrm{C}$ with fecundity, time of $50 \%$ of emerged eggs, growth population rate, intrinsic rate of increase and finite rate of increase expressing the highest values among the evaluated temperatures. Special attention is suggested on field crops grown at this temperature, because the insect pest will have a high potential to affect the coffee crop with high intensity.

Whole the information obtained is fundamental for growers, researchers, epidemiologists and agronomist to develop trust and precise monitoring and prediction schemes as well as for designing integrated pest management programs for L. coffeella, based on the growth population to a regional scale.

\section{Acknowledgements}

We thank Janet W. Reid, JWR Associates, for the English revision.

\section{References}

[1] Pereira EJG, Picanço MC, Bacci L, Crespo ALB, Guedes RNC. (2007) Seasonal mortality factors of the coffee leaf miner, Leucoptera coffeella. Bulletin of Entomological Research 97: 421-432. Doi: https://doi.org/10.1017/S0007485307005202

[2] Parra JRP, Reis PR. (2013) Manejo integrado para as principais pragas da cafeicultura no Brasil. Visão Agrícola 8: $47-50$.

[3] Guerreiro Filho O. (2006) Coffee leaf miner resistance. Brazilian Journal Plant Physiology 18: 109-117. Doi: http://dx.doi.org/10.1590/S1677-04202006000100009
[4] Parra JRP. (1985) Biologia comparada de Perileucoptera coffeella (Guérin-Mèneville, 1842) (Lepidoptera: Lyonetiidae) visando ao seu zoneamento ecológico no estado de São Paulo. Revista Brasileira de Entomologia 29: 45-76.

[5] Martins M, Guimarães-Mendes AN, Nogueira-Alvarenga I. (2004) Incidência de pragas e doenças em agroecossistemas de café orgânico de agricultores familiares em Poço FundoMG. Ciência e Agrotecnologia 28: 1306-1313. Doi: http://dx.doi.org/10.1590/S1413-70542004000600012

[6] Vega FE, Posada F, Infante F. (2006) Coffee insects: ecology and control, In: PIMENTEL, D. (Ed.). Encyclopedia of pest management. M. Dekker, London, UK. pp. 1-4. Doi: 10.1081/E-EPM-120042132.

[7] Harrison WW, King EG, Ouzts JD. (1985). Development of Trichogramma exiguum and T. pretiosum at five temperature regimes. Environmental Entomology 14: 118-121. Doi: https://doi.org/10.1093/ee/14.2.118

[8] Noldus L P. (1989) Semiochemicals, foraging behavior and quality of entomophagous insects for biological control. Journal of Applied Entomology 108: 425-451. Doi: https://doi.org/10.1111/j.1439-0418.1989.tb00478.x

[9] Gotelli NJ. (2001) A primer of ecology. 3rd Edition: Sinauer Associates, Sunderland, MA, 283 p.

[10] Maia HNM, Luiz AJB, Campanhola C. (2000) Statistical inference on associated fertility life table parameters using jackknife technique: computational aspects. Journal Economic Entomology 93: 511-518. Doi: 10.1603/0022-0493-93.2.511.

[11] Parra JRP, Haddad, ML, Silveira Neto S. (1995) Tabela de vida de fertilidade de Perileucoptera coffeella (GuérinMèneville, 1842) (Lepidoptera, Lyonetiidae) em três temperaturas. Revista Brasileira de Entomologia 39: 125129.

[12] R Core Team (2013). R: A language and environment for statistical computing version 3.2.3. R Foundation for Statistical Computing, Vienna, Austria. URL http://www.R-project.org/.

[13] Meyer J S, Ingersoll CG, McDonald L, Boyce, MS. (1986) Uncertainty in population growth rates: jackknife vs. bootstrap technique. Ecology 67: 1156-1166.

[14] Notley FB. (1956) The Leucoptera leaf miners of coffee on Kilimanjaro. II. Leucoptera caffeina Wshbn. Bulletin of Entomological Research 46: 899-912. Doi: https://doi.org/10.1017/S0007485300022501 
[15] Magalhães FL, Fernandez AJ, Demuner MC, Picanço P, Guedes RNC. (2010) Phenolics and coffee resistance to the leaf miner Leucoptera coffeella (Lepidoptera: Lyonetiidae). Journal Economy Entomology 103: 1438-1443. Doi: $10.1603 / \mathrm{ec} 09362$.

[16] Katiyar KP, Ferrer F. (1968) Rearing technique, biology and sterilization of the coffee leaf miner Leucoptera coffeella Guér (Lepidoptera: Lyonetiidae). In: International Atomic Energy Agency. Isotopes and Radiation in Entomology. AIEA, Vienna, Austria, pp. 165-175.

[17] Sutherland TD, Young JH, Wiesman S, Hayashi CY, Merritt D. (2010) Insect silk: one name, many materials. Annual Review of Entomology 55: 171-188. Doi: 10.1146/annurevento-112408-085401.
[18] Southwood TRE. (1978) The construction, description and analysis of age-specific life-tables. In: Southwood, TRE. Ecological methods: With particular reference to the study of insect populations. Chapman and Hall, London, UK. p. 356387.

[19] Ghini R, Hamada R, Pedro Junior MP, Marengo JA, Gonçalves RRV. (2008) Risk analysis of climate change on coffee nematodes and leaf miner in Brazil. Pesquisa Agropecuaria Brasileira 43: 187-194. Doi: http://dx.doi.org/10.1590/S0100-204X2008000200005

[20] Neubert M, Caswell H. (2000) Demography and dispersal: calculation and sensitivity analysis of invasion speed for structured populations. Ecology 8: 1613-1628. Doi: https://doi.org/10.1890/00129658(2000)081[1613:DADCAS]2.0.CO;2 